\title{
THALLIUM IN THE MARINE ENVIRONMENT: FIRST ECOTOXICOLOGICAL ASSESSMENTS IN THE GUADALQUIVIR ESTUARY AND ITS POTENTIAL ADVERSE EFFECT ON THE DOÑANA EUROPEAN NATURAL RESERVE AFTER THE AZNALCÓLLAR MINING SPILL (SW SPAIN) \\ TALIO EN EL MEDIO MARINO: PRIMERA VALORACIÓN ECOTOXICOLÓGICA EN EL ESTUARIO DEL GUADALQUIVIR Y SU EFECTO POTENCIAL ADVERSO EN LA RESERVA NATURAL DE DOÑANA DESPUÉS DEL VERTIDO MINERO DE AZNALCÓLLAR (SW DE ESPAÑA)
}

\author{
T.A. DelValls ${ }^{1}$ \\ V. Sáenz ${ }^{2}$ \\ A.M. Arias ${ }^{2}$ \\ J. Blasco ${ }^{2}$ \\ ${ }^{1}$ Departamento de Química Física \\ Facultad de Ciencias del Mar \\ Universidad de Cádiz \\ Apartado 40 \\ 11510 Puerto Real, Cádiz, España \\ E-mail: angel.valls@uca.es \\ 2 Instituto de Ciencias Marinas de Andalucía, CSIC \\ Campus Universitario Río San Pedro \\ 11510 Puerto Real, Cádiz, España
}

Recibido en septiembre de 1998; aceptado en marzo de 1999

\begin{abstract}
Thallium (Tl) is an extremely toxic but little-studied element in the marine environment and practically no information has been reported on the levels of $\mathrm{Tl}$ in marine organisms. After the Aznalcóllar mining spill (April 1998), high levels of metals were put into the environment. This acidcontaminated medium was responsible for the initial pollution effects measured in the Guadiamar River, which is an affluent of the Guadalquivir River and very close to the biggest natural reserve in Europe (Doñana). Four different species were used in the monitoring from April to September 1998 and a sediment field bioassay to check bioacumulation was performed. We present the first ecotoxicological evaluation of the mining spill in the Guadalquivir River, with reference to Tl, a little-known metal. Also, $\mathrm{Pb}$ and $\mathrm{Cd}$ data were compared to $\mathrm{Tl}$ during field sediment testing. Results show low levels of this metal in all of the organisms studied and they do not show any increase in the level of this metal, ranging from 40 to $90 \mathrm{ng} \mathrm{g}^{-1}, 80$ to $210 \mathrm{ng} \mathrm{g}^{-1}, 15$ to $98 \mathrm{ng} \mathrm{g}^{-1}$ and 75 to 125 whole body dry weight for Scrobicularia plana, Liza ramada (muscle), Crassostrea angulata and Uca tangeri, respectively. These are the first field data of $\mathrm{Tl}$ concentration measured using estuarine organisms. Field sediment toxicity test results
\end{abstract}


Ciencias Marinas, Vol. 25, No. 2, 1999

confirm those obtained during the monitoring: $\mathrm{Tl}$ is not bioaccumulated by the organisms $(C$. angulata $)$ used in the test. The sequence in bioaccumulation of metals was $\mathrm{Cd}>\mathrm{Pb}>\mathrm{Tl}$. Both studies, bioaccumulation and sediment toxicity, should be maintained during the next few years to really evaluate the potential effect of the mining spill on the ecosystem and society.

Key words: thallium, bioaccumulation, field sediment toxicity, Doñana, Guadalquivir estuary.

\section{RESUMEN}

El talio (Tl) es un elemento extremadamente tóxico aunque poco estudiado en el medio marino y la información sobre niveles de $\mathrm{Tl}$ en organismos marinos con anterioridad al presente trabajo es prácticamente nula. Después del vertido minero de Aznalcóllar (abril de 1998) se produjo la entrada de elevados niveles de metales en el medio marino. La acidez del medio fue la responsable de los efectos contaminantes iniciales registrados en el río Guadiamar, el cual es un afluente del río Guadalquivir y está muy próximo a la mayor reserva natural de Europa (Doñana). En el seguimiento realizado de abril a septiembre de 1998 se utilizaron cuatro especies diferentes y se llevó a cabo un bioensayo de sedimento in situ para estudiar el proceso de bioacumulación. En este trabajo se presenta la primera evaluación ecotoxicológica del vertido minero en el río Guadalquivir y se hace referencia a un metal poco conocido como Tl. El Pb y Cd también fueron analizados en el test de sedimento in situ. Los resultados muestran bajos niveles de $\mathrm{Tl}$ en todos los organismos estudiados y ningún incremento en los niveles, que varían de 40 a $90 \mathrm{ng} \mathrm{g}^{-1}, 80$ a $210 \mathrm{ng} \mathrm{g}^{-1}, 15$ a $98 \mathrm{ng} \mathrm{g}^{-1}$ y 75 a $125 \mathrm{ng} \mathrm{g}^{-1}$ peso seco para Scrobicularia plana, Liza ramada, Crassostrea angulata y Uca tangeri, respectivamente. Los resultados para S. plana, C. angulata y $U$. tangeri corresponden al cuerpo completo, mientras que para $L$. ramada al músculo. Éstos son los primeros resultados de concentración de Tl medidos en organismos de estuario. El ensayo de toxicidad in situ confirma lo hallado en el seguimiento: estos organismos ( $C$. angulata) no bioacumulan este metal. La secuencia en la bioacumulación de metales fue $\mathrm{Cd}>\mathrm{Pb}>\mathrm{Tl}$. Ambos estudios, bioacumulación y toxicidad del sedimento, deberían continuarse durante los próximos años para poder evaluar realmente el efecto potencial del vertido minero sobre el ecosistema y el entorno socio-económico.

Key words: talio, bioacumulación, toxicidad del sedimento in situ, Doñana, estuario del Guadalquivir.

\section{INTRODUCTION}

\section{Historic considerations}

Thallium, from the Greek $\theta \alpha \lambda \lambda \varepsilon i v$ (becoming green) and $\theta \alpha \lambda \lambda$ o (green twig), was discovered independently by Crookes and by Lamy in 1861 . Until the early years of the 20th century, thallium salts were used extensively to treat syphilis (since 1883), to reduce night sweats in tuberculosis patients (since 1898), for epilation (since 1897), to treat ring-worm disease of the scalp (since 1919) and to kill rodents (since 1920). Thallium salts are odorless, tasteless and extremely toxic; these aspects made thallium compounds a choice for homicidal poisoning

\section{INTRODUCCIÓN}

\section{Consideraciones históricas}

El elemento talio, del griego $\theta \alpha \lambda \lambda \varepsilon \varepsilon v$ (ponerse verde) y $\theta \alpha \lambda \lambda \mathrm{o} \varsigma$ (rama verde), fue descubierto en 1861 de forma independiente por Crookes y por Lamy. Hasta los primeros años del siglo XX, las sales de talio se usaron ampliamente para tratar la sífilis (desde 1883), para reducir los sudores nocturnos en enfermos de tuberculosis (desde 1898), para la depilación (desde 1897), para tratar la enfermedad de la tiña en el cuero cabelludo (hasta 1919) y para matar roedores (desde 1920). Las sales de talio son inodoras, insípidas y extremadamente tóxicas; estos aspectos 
DelValls et al.: Thallium in the marine environment

during the early part of the century. Following the US federal ban of thallium as a rodenticide in 1972, thallium containing pesticides no longer remained available in most industrialized countries (Beliles, 1994). Thallium is one of the priority pollutants, along with lead, cadmium and mercury, listed by the US Environmental Protection Agency (Keith and Telliard, 1979). Today, rodents are becoming increasingly resistant towards dicoumarol-based products, and thallium is again being taken into consideration as an efficient rodenticide. The application of thallium in medicine has been almost entirely abandoned because of its toxicity, but thallium is now increasingly used in the manufacturing of crystals, imitation jewelry, dyes, pigments, electric and electronic equipment, semiconductors, optical systems, infrared spectrometers (thallium bromine iodide crystals), low-temperature thermometers, scintillation counters and fiberglass cables for communication. Thallium-201 (physical half-life 3.08 days) is widely utilized for myocardial imaging because it behaves in a similar way to potassium and thus readily enters myocardial cells. For these reasons, thallium exposure might again become a risk in the future (Manzo et al., 1995).

\section{Occurrence and properties of thallium}

Thallium is a rare, although widely spread element with average concentrations of $0.49 \mathrm{ppm}$ in the continental crust and of $0.013 \mathrm{ppm}$ in the oceanic crust. Although the average thallium content in the earth's crust is only $6 \cdot 10^{-5}$ weight $\%$, it is higher than some of the more commonly studied elements such as lead, cadmium or bismuth (Korenman, 1963). It is a minor constituent of many iron and copper sulfides and selenite ores, and occurs in larger concentrations in crooksite $(\mathrm{Cu}, \mathrm{Tl}, \mathrm{Ag})_{2} \mathrm{Se}$, found in Sweden and Brazil; in lorandite $\left(\mathrm{TlAsS}_{2}\right)$, found in Greece and the USA; in hutchinsonite ([Tl, $\mathrm{Cu}, \mathrm{Ag}]_{2} \mathrm{~S} . \mathrm{PbS} .2 \mathrm{As}_{2} \mathrm{~S}_{3}$ ), found in Switzerland; in orabite $\left(\mathrm{TlAs}_{2} \mathrm{SbS}_{5}\right)$, found in Brazil and hicieron que los compuestos de talio fuesen elegidos para homicidios por envenenamiento durante los primeros años del siglo XX. Después de que el gobierno federal de los Estados Unidos prohibiera el talio como rodenticida en 1972, dejaron de utilizarse en la mayoría de los países industrializados los pesticidas que contenían este metal (Beliles, 1994). El talio es uno de los principales contaminantes, junto con el plomo, cadmio y mercurio, en el listado de la agencia de protección medioambiental de los Estados Unidos (Keith y Telliard, 1979). En la actualidad, debido a que los roedores se están haciendo resistentes a los productos que emplean dicoumarol, se está volviendo a considerar de nuevo al talio como un rodenticida eficaz. Las aplicaciones del talio en medicina se han abandonado casi por completo debido a su toxicidad, pero está aumentando actualmente el uso de este metal en la manufactura de cristales, imitación de joyas, tintes, pigmentos, equipos eléctri$\cos$ y electrónicos, semiconductores, sistemas ópticos, espectrofotómetros de IR (cristales de yoduro de bromo y talio), termómetros para la medición de bajas temperaturas, contadores de centelleo y cables de fibra de vidrio para telecomunicación. El talio-201 (tiempo de vida medio 3.08 días) se utiliza ampliamente para visualizar el miocardio ya que se comporta de un modo similar al potasio $\mathrm{y}$, por tanto, penetra fácilmente en las células de miocardio. Por estas razones, la exposición al talio podría convertirse de nuevo en un riesgo en el futuro (Manzo et al., 1995).

\section{Presencia y propiedades del talio}

El talio es un elemento raro, aunque está ampliamente extendido, con una concentración media de $0.49 \mathrm{ppm}$ en la corteza terrestre y de $0.013 \mathrm{ppm}$ en la corteza oceánica. Aunque el contenido medio en peso del talio en la corteza terrestre es sólo de un $6 \cdot 10^{-5} \%$, éste es superior al de muchos de los elementos más estudiados, como el plomo, cadmio o bismuto (Korenman, 1963). El talio es un constituyente minoritario de algunos sulfuros de hierro y cobre y de la selenita, y está 
Ciencias Marinas, Vol. 25, No. 2, 1999

the USA; and in berzelianite $\left([\mathrm{Cu}, \mathrm{Ag}, \mathrm{Tl}]_{2} \mathrm{Se}\right)$, found in Germany. Thallium has also been detected in meteorites $\left(0.001-0.2 \mu \mathrm{g} \mathrm{g}^{-1}\right)$ and in lunar samples $\left(0.0006-0.0024 \mu \mathrm{g} \mathrm{g}^{-1}\right)$. Only lorandite contains sufficiently large thallium concentrations (up to 60\%) to make separate exploitation profitable: however, most commercial thallium is isolated form flue dusts resulting from burning pyrite or from smelting and refining lead or zinc, or as a byproduct of cadmium production. Annual world-wide production of thallium is about 35 tons, with ore reserves in the order of 1.4.103 tons (Wedepohl, 1991).

The presence of thallium in the environment and its effects on the biota have not received much attention, especially in aquatic environments, due in part, to difficulties in measuring this metal. Small amounts of thallium are detected in many materials in the environment. The concentration in sea water is $0.01 \mu \mathrm{g} \mathrm{L}^{-1}$ and in river water, $0.04 \mu \mathrm{g} \mathrm{L}^{-1}$. However, concentrations as high as $800 \mu \mathrm{g} \mathrm{L}^{-1}$ have been reported for ground water near waste deposits. Hard coal contains $0.062 \mathrm{ppm}$ and brown coal $0.03 \mathrm{ppm}$ of thallium (Wedepohl, 1991). Less than $1 \mathrm{ng} \mathrm{m}^{-3}$ of thallium is present in ambient air. The recent development of an ultra-sensitive laser-excited atomic fluorescence spectrometric method for thallium determination has made possible direct analysis of aqueous samples without any pre-concentration (Cheam et al., 1996).

Thallium concentration in food is generally very low and depends directly on thallium concentrations in the adjacent environmental compartments (i.e., soil). Mean concentrations of thallium in cereals, fruit and vegetables are about $0.05-0.1 \mathrm{mg} \mathrm{kg}^{-1}$ fresh weight. Mushrooms can, however, contain very high thallium concentrations (up to $1.2 \mathrm{mg} \mathrm{kg}^{-1}$ fresh matter), depending on the area where they had been harvested. Animal feed containing as little as $0.5 \mathrm{mg} \mathrm{kg}^{-1}$ of thallium and given over several months can raise levels in the kidney of the animal to more than $1 \mathrm{mg} \mathrm{kg}^{-1}$ (Oheme, 1978). Human hair normally contains about $0.018 \mathrm{ppm}$ of thallium; as little as presente en elevadas concentraciones en la crooksita $(\mathrm{Cu}, \mathrm{Tl}, \mathrm{Ag})_{2} \mathrm{Se}$, encontrada en Suecia y Brasil; lorandita $\left(\mathrm{TlAsS}_{2}\right)$, encontrada en Grecia y EUA; hutchinsonita ([Tl, Cu, Ag $]_{2} \mathrm{~S} . \mathrm{PbS} .2 \mathrm{As}_{2} \mathrm{~S}_{3}$ ), encontrada en Suiza; orabita $\left(\mathrm{TlAs}_{2} \mathrm{SbS}_{5}\right)$, encontrada en Brasil y EUA; y berzelianita ([Cu, Ag, $\mathrm{Tl}]_{2} \mathrm{Se}$ ), encontrada en Alemania. El talio se ha detectado también en meteoritos (0.001-0.2 $\left.\mu_{\mathrm{g} \mathrm{g}^{-1}}\right)$ y en muestras lunares (0.0006$\left.0.0024 \mu \mathrm{g} \mathrm{g}^{-1}\right)$. Solamente la lorandita contiene una concentración de talio suficientemente elevada (superior al 60\%) como para llevar a cabo una explotación rentable, aunque la mayor parte del talio comercial se obtiene de las cenizas resultantes de la combustión de la pirita, o de la fundición y refinado del plomo o del zinc, o como un subproducto de la producción de cadmio. La producción mundial anual de talio es aproximadamente 35 toneladas, con reservas de mineral del orden de $1.4 \cdot 10^{3}$ toneladas (Wedepohl, 1991).

La presencia de talio en el medio ambiente y sus efectos sobre la biota no ha recibido mucha atención, especialmente en el medio acuático, debido en parte a las dificultades analíticas de este metal. La cantidad de talio detectada en muchos compartimentos ambientales es pequeña. La concentración en agua de mar es $0.01 \mu \mathrm{g} \mathrm{L}^{-1}$ y en agua dulce, $0.04 \mu \mathrm{g} \mathrm{L}^{-1}$. De cualquier manera, en aguas subterráneas próximas a depósitos de vertidos se han encontrado concentraciones de talio tan elevadas como $800 \mu \mathrm{g} \mathrm{L}^{-1}$. La hulla contiene $0.062 \mathrm{ppm}$ y el lignito $0.03 \mathrm{ppm}$ de talio (Wedepohl, 1991). En la atmósfera, la concentración de talio es inferior a $1 \mathrm{ng} \mathrm{m}^{-3}$. El desarrollo reciente de un método analítico ultra sensible para la determinación de talio por espectrofotometría de fluorescencia atómica mediante excitación por láser ha hecho posible el análisis directo de muestras acuosas sin necesidad de utilizar ningún procedimiento de preconcentración (Cheam et al., 1996).

La concentración de talio en los alimentos es, generalmente, muy baja y depende directamente de la concentración de talio en los compartimentos ambientales adyacentes (p.e., suelos). La 
DelValls et al.: Thallium in the marine environment

$5 \mathrm{ppm}$ is sufficient for poissoning. The threshold value for soluble thallium compounds at the workplace recommended by the Conference of Governmental Industrial Hygienists (ACGIH, 1995) is $0.1 \mathrm{mg} \mathrm{m}^{-3}$.

\section{Biological function, metabolism and general toxicity of thallium}

Thallium compounds in oxidation states 1+ are stable and have properties similar to potassium; thallium compounds in oxidation states 3+ resemble aluminum, have strong oxidizing properties and are slowly converted to the monovalent state. The marked toxicity of thallium compounds can be explained on the basis of their affinity to amino- imino-sulfhydryl groups at active enzymatic centers and of their chemical similarity with potassium, which is involved in many cellular and membrane processes. Thus, thallium ions can substitute for those of potassium in the activation of $\mathrm{Na}^{+}, \mathrm{K}^{+}$ATPase. This substitution may allow $\mathrm{Tl}^{+}$to move across cell membranes, accumulate in the cell and then attack the mitochondrial respiratory chain (Spencer et al., 1973). These processes are thought to play a role in thallium-induced neuropathy.

Thallium is rapidly and nearly entirely absorbed from the skin and from the mucous membranes of the mouth and the gastrointestinal tract. More than $90 \%$ of water-soluble thallium salts are absorbed from the human gastrointestinal tract. Some thallium is rapidly excreted mainly into the feces, but other components have halftimes of about two weeks. Thallium-poisoned people display the highest concentrations in the kidney, followed, in decreasing order, by the bone, stomach, intestine, spleen, liver, muscle, lung and brain. Doses as small as $8 \mathrm{mg} \mathrm{kg}^{-1}$ can be lethal to humans. Principal early symptoms of thallium poisoning are gastroenteritis, fever, tachycardia and, in serious cases, delirium and coma. After 2-5 days, lesions in liver and kidney, peripheral neuropathy (polyneuritis), eruptions of the skin and encephalopathy develop. People concentración media de talio en cereales, frutas y verduras es alrededor de 0.05 a $0.1 \mathrm{mg} \mathrm{kg}^{-1}$ peso fresco, aunque los champiñones pueden llegar a tener concentraciones muy elevadas de talio (superiores a $1.2 \mathrm{mg} \mathrm{kg}^{-1}$ peso fresco), dependiendo de la zona en la que han sido cultivados. Los animales que ingieren alimentos durante varios meses que contienen concentraciones de talio tan pequeñas como $0.5 \mathrm{mg} \mathrm{kg}^{-1}$, pueden alcanzar niveles en el riñón de más de $1 \mathrm{mg} \mathrm{kg}^{-1}$ (Oheme, 1978). El cabello humano contiene normalmente concentraciones de talio de 0.018 ppm; una concentración tan pequeña como 5 ppm es suficiente para producir envenenamiento. El valor límite en el puesto de trabajo habitual recomendado por la Conferencia de Higienistas Industriales Gubernamentales (ACGIH, 1995) para los compuestos solubles de talio es de $0.1 \mathrm{mg} \mathrm{m}^{-3}$.

\section{Función biológica, metabolismo y toxicidad general del talio}

Los compuestos de talio con estado de oxidación $1+$ son estables y tienen propiedades similares a las del potasio; los compuestos de talio con estado de oxidación 3+ son parecidos al aluminio, tienen una fuerte capacidad oxidante y se convierten lentamente al estado monovalente. La gran toxicidad de los compuestos de talio se puede explicar por su afinidad hacia los grupos aminoimino-sulfhidrilos de los centros enzimáticos activos, y a su semejanza química con el potasio, lo que le permite introducirse en muchos procesos celulares y de membrana. Por lo tanto, los iones de talio pueden sustituir a los de potasio en la activación de la $\mathrm{Na}^{+}, \mathrm{K}^{+}$ATPasa. Esta sustitución le puede permitir al talio moverse a través de la membrana celular, acumularse en la célula y entonces atacar la cadena respiratoria en la mitocondria (Spencer et al., 1973). Se cree que estos procesos juegan un papel importante en la neuropatía inducida por el talio.

La piel y las membranas mucosas de la boca y del tracto intestinal absorben rápidamente y casi por completo el talio. El tracto gastrointestinal 
Ciencias Marinas, Vol. 25, No. 2, 1999

surviving the acute stages show a characteristic loss of hair as well as atrophy of nails and skin.

Munch (1934) assembled 778 cases of human thallium poisoning, of which 46 were fatal. Today, thallium is no longer readily available; thus accidental poisonings or suicides have become rare. At the workplace, people can be exposed during the handling of pyrites, flue dusts, etc., and this would occur most often in combination with exposure to lead, copper, indium and arsenic.

\section{Scope of this ecotoxicological study related to the Aznalcóllar mining spill}

We have been talking about the human toxicity of thallium increasing when it is in combination with lead, copper, indium and arsenic. Three of these metals were in high concentrations in the toxic waste effluents from the pyrite mine in Aznalcóllar. When the pool containing toxic mud and water was broken in April 1998, these acid effluents spilled out into the adjacent river (the Guadiamar River) and most of the fauna was killed because of the loss of oxygen in the water. The acid water worked like an acid during an acid-base titration. After this, the problem started with the high heavy metal concentrations in the environment. We have focused this paper on thallium with some reference to other metals, such as cadmium and lead, because thallium is one of the unknown metals in estuaries and marine environments. Also, the biggest natural reserve in Europe (Doñana) is very close to the mining spill and in dynamic contact with the Guadalquivir (the big river in Arabic language) estuary, into which the Guadiamar River flows. The first estimations of the toxic mud and water indicated a potential pollution due to thallium. Since the Guadalquivir estuary is an important area, ecologically because it is in a dynamic environmental equilibrium with the Doñana Natural Park and socially because it is an important area for tourism in Spain and Europe, the social alarm was raised and an expert commission from the Consejo Superior de Investigaciones humano absorbe más del $90 \%$ de las sales de talio solubles en agua. Parte del talio se excreta rápidamente a través de las heces principalmente, pero algunos compuestos de este elemento poseen un tiempo aproximado de vida medio del orden de dos semanas. Las personas envenenadas con talio muestran las mayores concentraciones en el riñón, seguido, en orden decreciente, por los huesos, el estómago, el intestino, el bazo, el hígado, los músculos, los pulmones y el cerebro. Dosis tan bajas como $8 \mathrm{mg} \mathrm{kg}^{-1}$ pueden ser letales para el hombre. Los primeros síntomas importantes de envenenamiento por talio son gastroenteritis, fiebre, taquicardia y, en casos serios, delirio y coma. Después de 2-5 días se desarrollan lesiones en el hígado y en el riñón, neuropatías periféricas (polineuritis), erupciones de la piel y encefalopatías. La gente que sobrevive a las etapas más agudas muestra una pérdida característica de cabello, así como atrofia de la piel y de las uñas.

Munch (1934) recopiló 778 casos de envenenamiento humano por talio, de los cuales 46 fueron mortales. Actualmente, no es posible conseguir fácilmente talio, por lo que los envenenamientos accidentales o los suicidios son raros. Las exposiciones ocupacionales a talio se producen como consecuencia de la manipulación de la pirita, cenizas, etc., y se da, con frecuencia, de manera simultánea a la exposición con otros metales como plomo, cobre, indio y arsénico.

\section{Alcance del estudio ecotoxicológico en relación con el vertido minero de Aznalcóllar}

Se ha hablado de que la toxicidad del talio en el hombre aumenta cuando este metal se presenta junto al plomo, cobre, indio y arsénico. En los efluentes residuales tóxicos vertidos por la mina de pirita de Aznalcóllar, tres de estos metales se encontraron en concentraciones elevadas. Cuando se produjo, en abril de 1998, la ruptura de la presa que contenía el agua y los lodos tóxicos, estos efluentes ácidos fueron vertidos en el río adyacente (río Guadiamar) y la mayor parte de la fauna desapareció como consecuencia de la pérdida de oxígeno en las aguas del río. Las aguas ácidas 
Científicas was set up to look for solutions and for monitoring and evaluating the effect of this ecological disaster.

We present here (as part of an integrated assessment of the estuary) the first measurements of thallium in estuarine organisms and also the first ecotoxicological evaluations using the oyster Crassostrea angulata, performing a field sediment toxicity test that is related to thallium concentrations measured in organisms. Organisms have been used in sediment ecotoxicity studies to measure the bioavailability of contaminants through tissue analysis. These two kinds of ecotoxicological studies were performed using different organisms, for monitoring and for field toxicity testing.

\section{MATERIALS AND METHODS}

Individuals of four different species, Crassostrea angulata, Scrobicularia plana, Liza ramada and Uca tangeri, were collected, every 15 days, from different stations (A and B, C, D, and $\mathrm{D}$ and $\mathrm{E}$, respectively) in the Guadalquivir estuary from April to August 1998. Locations and species collected are shown in figure 1. Also, a field toxicity test was designed to evaluate thallium (and other metals) bioaccumulation to have an ecotoxicological assessment of the potential effect in the estuary from the mining spill. Oyster individuals $(C$. angulata) from uncontaminated areas in the Bay of Cádiz were placed at station B in the Guadalquivir estuary during a period of two months and samples were collected monthly to evaluate heavy metal concentrations in the body.

Samples were transported to the laboratory in a portable ice-box in a period of less than two hours. Individuals of the species S. plana, $C$. angulata and $U$. tangeri were put through a depuration process by means of a continuous flux system with clean sea water for a minimum of 48 hours and starved. This process eliminates any intestinal contents and, per ende, the contamination sources of the heavy metals measured.

At the end of the depuration process and after dissection, soft tissues of clams (S. plana) and funcionaron de manera similar a como lo hace un ácido durante una valoración ácido-base. Después de esto, el problema comenzó con las elevadas concentraciones de metales pesados en el medio ambiente. Este trabajo se ha enfocado al talio, y se han tomado como referencia otros elementos traza, como el cadmio y el plomo, ya que el talio es uno de los metales menos conocidos en los sistemas estuáricos y marinos. Por otro lado, la mayor reserva natural de Europa (Doñana) está muy próxima al lugar en el que se produjo el vertido minero y en contacto dinámico con el estuario del Guadalquivir (en lengua árabe, el gran río), en el que desemboca el río Guadiamar. Las primeras estimaciones del agua y de los lodos tóxicos pusieron de manifiesto una contaminación potencial por talio. Debido a que el estuario del Guadalquivir es una zona muy importante, tanto desde un punto de vista ecológico, ya que está en equilibrio ambiental dinámico con el Parque Natural de Doñana, como desde un punto de vista social, dado que se trata de un área importante para el turismo procedente de España y del resto de Europa, se produjo una alarma social y se constituyó una comisión de expertos del Consejo Superior de Investigaciones Científicas para buscar soluciones y realizar un seguimiento y evaluación del efecto de este desastre ecológico.

Se presentan aquí (como parte de una valoración integrada en el estuario) las primeras determinaciones analíticas de talio en organismos marinos y también las primeras evaluaciones ecotoxicológicas realizadas en la ostra Crassostrea angulata mediante un test de toxicidad de sedimento llevado a cabo in situ, que guarda relación con las concentraciones de talio medidas en organismos. En los estudios de ecotoxicidad se han utilizado organismos para medir la biodisponibilidad de los contaminantes mediante el análisis de sus tejidos. Esto se ha hecho en su mayor parte in situ, utilizando tanto poblaciones nativas como organismos introducidos en jaulas. Estos dos tipos de estudios ecotoxicológicos se realizaron utilizando diferentes organismos para el seguimiento y para el test de toxicidad in situ. 


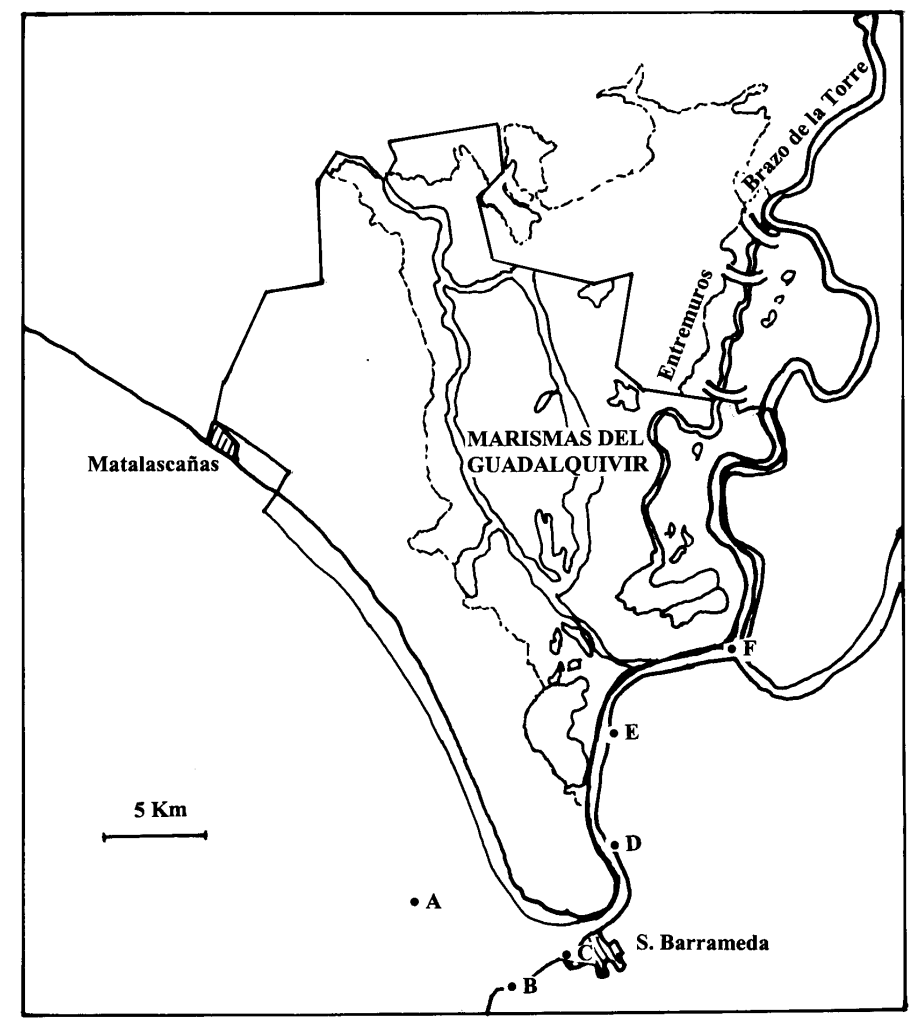

Figure 1. Map showing the sampling stations in the Guadalquivir estuary.

Figura 1. Mapa de las estaciones de muestreo en el estuario del Guadalquivir.

oyster ( $C$. angulata) were taken to perform the analysis. Specimens of $U$. tangeri were divided into female and male. The male specimens were divided into body and pincer. For the crabs, either soft tissue or hard pieces from the external skeleton were taken into account for the analysis. The heavy metal analyses in $L$. ramada were performed in the liver and the muscle.

Pools of 10 to 15 specimens were employed in each case (giving, in general, three replicates per sample); they were liophilized until constant weight was reached. Samples were digested with $\mathrm{HNO}_{3}$ Suprapur (Merck) according to the procedure of Amiard et al. (1987) and analyzed by

\section{MATERIAL Y MÉTODOS}

Se llevaron a cabo muestreos de las especies Crassostrea angulata, Scrobicularia plana, Liza ramada y Uca tangeri en diferentes estaciones seleccionadas a lo largo del estuario del Guadalquivir (A y B, C, D, y D y E, respectivamente), con una periodicidad quincenal entre mayo y agosto de 1998. En la figura 1 se señalan las estaciones y las especies muestreadas en cada una de ellas. Por otro lado, se diseñó un test de toxicidad in situ para evaluar la bioacumulación de talio (y otros metales) con el fin de obtener una valoración ecotoxicológica del efecto potencial 
GFAAS (Perkin Elmer 4100 ZL) with Zeeman background correction. $\mathrm{Pd}$ and $\mathrm{Mg}\left(\mathrm{NO}_{3}\right)_{2}$ were used as matrix modifiers.

\section{RESULTS AND DISCUSSION}

\section{Thallium concentrations in field-collected organisms}

The concentrations of thallium, in dry weight, in the different species used in this study are summarized in figures 2 and 3. Figure 2 shows the results for $S$. plana and L. ramada. For the clam, the results ranged from 42 to $100 \mathrm{ng} \mathrm{g}^{-1}$ dry weight; no bioaccumulation trends were recorded. For the fish, two different tissues, muscle and liver, were used in the analysis; thallium concentrations were lower in the muscle than in the liver. The results do not show an increase in the thallium levels through time in these field-collected organisms.

Table 1 shows the results of thallium concentrations measured in male and female specimens of the crab $U$. tangeri at two different stations in the Guadalquivir estuary. Differences between stations and male and female specimens were not significant $(P<0.01)$. The results show a slight effect of accumulation, which should be confirmed in further analysis because of the small frequency of the sampling dates (only two sampling dates, one in June and one in July). The data ranged from 59 to $128 \mathrm{ng} \mathrm{g}^{-1}$ dry weight.

The results of thallium concentrations measured in the oyster $C$. angulata collected at two different stations in the Guadalquivir River are shown in figure 3 . The data ranged from 20 to $90 \mathrm{ng} \mathrm{g}^{-1}$ dry weight. These results show considerable variability, although they do not indicate a bioaccumulation process for this organism. The differences between stations were not significant $(\mathrm{P}<0.01)$.

As no data for other similar marine organisms are available, it has not been possible to compare these data. However, they were compared to data reported by Borgmann et al. (1998) for the freshwater amphipod Hyalella azteca exposed to del vertido minero en el estuario. Se colocaron en la estación B del estuario del Guadalquivir individuos de ostra (C. angulata) procedentes de una zona no contaminada de la Bahía de Cádiz durante un periodo de dos meses y las muestras se recogieron mensualmente para evaluar la concentración de metales pesados en el cuerpo.

Las muestras se transportaron al laboratorio en una nevera portátil, en un periodo de tiempo inferior a dos horas desde que fueron recogidas. Los individuos de las especies $S$. plana, $C$. angulata y $U$. tangeri fueron sometidos a un proceso de depuración por medio de un sistema de flujo continuo con agua de mar y sin alimento durante un periodo mínimo de 48 horas, para eliminar el contenido intestinal y las posibles fuentes de contaminación de los metales pesados analizados.

Después de la depuración y de la disección se tomaron los tejidos blandos de las almejas $(S$. plana) y de las ostras (C. angulata) para analizarlos. Los individuos de la especie $U$. tangeri se dividieron en hembras y en machos. A los ejemplares machos se les separó el cuerpo de los quelípedos. En el caso de los cangrejos, se tomaron tanto el tejido blando como las piezas duras del esqueleto externo para su análisis conjunto. Los análisis de metales pesados en $L$. ramada se llevaron a cabo en el hígado y en el músculo.

Se utilizaron entre 10 y 15 ejemplares que fueron divididos entre lotes. Las muestras se liofilizaron hasta peso constante y se sometieron a un proceso de digestión ácida con $\mathrm{HNO}_{3}$ Suprapur (Merck), según el procedimiento de Amiard et al. (1987) y, posteriormente, se analizaron por GFAAS con corrección de fondo por efecto Zeeman (Perkin Elmer 4100 ZL). Se utilizaron Pd y $\mathrm{Mg}\left(\mathrm{NO}_{3}\right)_{2}$ como modificadores de matriz.

\section{RESULTADOS Y DISCUSIÓN}

\section{Concentración de talio en los organismos recogidos in situ}

Las concentraciones de talio en peso seco en las diferentes especies utilizadas en este trabajo se 
Ciencias Marinas, Vol. 25, No. 2, 1999
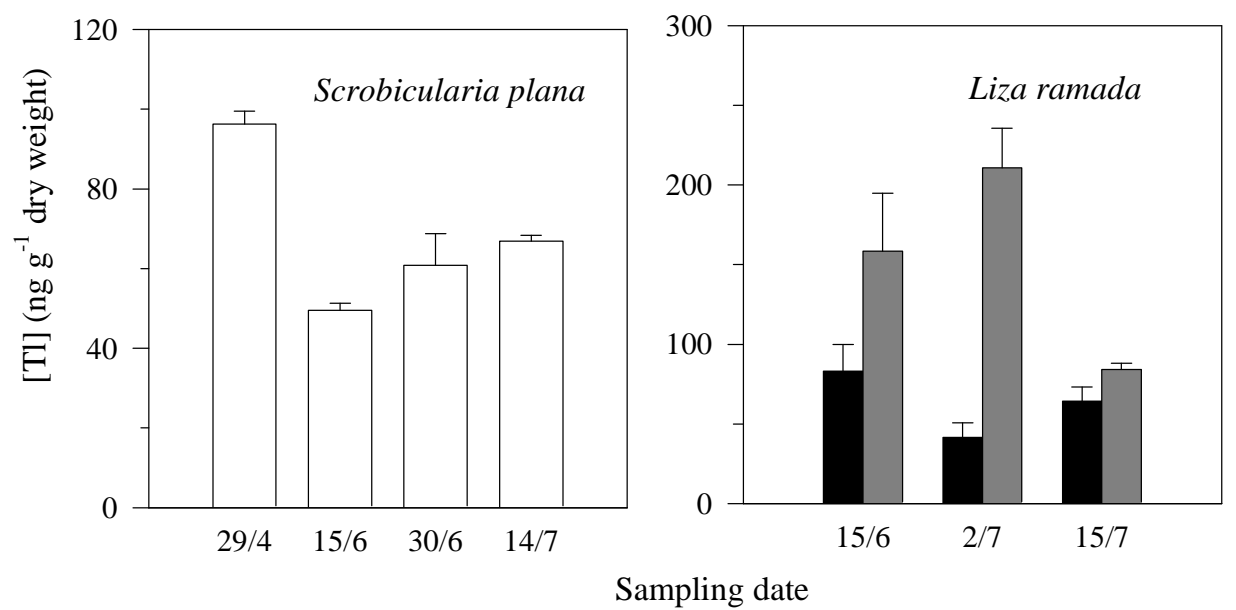

Figure 2. Histograms of dry-weight thallium concentrations measured in two different organisms, the clam Scrobicularia plana and the fish Liza ramada, at stations C and D, respectively, from the Guadalquivir estuary. The data are referred to soft body for the clam and for two different tissues (black bars for the muscle and gray bars for the liver) in the fish.

Figura 2. Histogramas de las concentraciones de talio en peso seco medidas en dos organismos diferentes, la almeja Scrobicularia plana y el pez Liza ramada, en las estaciones C y D, respectivamente, del estuario del Guadalquivir. Los datos se refieren al cuerpo blando para la almeja y a dos tejidos diferentes (barras negras para el músculo y barras grises para el hígado) para el pez.

thallium concentrations in sediments from Lake Ontario (table 2). From these results, only one maximum measured in the Guadalquivir River was higher than the minimum measured in amphipods from Lake Ontario. Also, it should be taken into account that this was for an adult fish (and using muscles with higher concentrations). From this comparison we can conclude that the levels of thallium measured in the marine organisms selected for this study were lower than those in the amphipods from Lake Ontario. This is another result that confirms our idea that there is no effect due to thallium in the Guadalquivir estuary. Nevertheless, monitoring studies of the organisms in the estuary should be carried out in the future (at present, the monitoring program continues, so there will be further results in the near future) to resumen en las figuras 2 y 3 . La figura 2 muestra los resultados para $S$. plana y L. ramada. En la coquina de fango ( $S$. plana), los resultados estuvieron comprendidos entre 42 y $100 \mathrm{ng} \mathrm{g}^{-1}$ en peso seco, no mostrándose ninguna tendencia a la bioacumulación de este metal. En el caso del pez lisa (L. ramada), se utilizaron para su análisis dos tejidos diferentes, músculo e hígado; las concentraciones de talio en el músculo fueron inferiores a las del hígado. Los resultados no muestran un incremento de los niveles de talio con el tiempo en estos organismos recogidos in situ.

Los resultados de la concentración de talio en ejemplares machos y hembras del cangrejo $U$. tangeri, procedentes de dos estaciones diferentes del estuario del Guadalquivir, se presentan en la tabla 1. Estos resultados muestran un ligero efecto 


\section{Crassostrea angulata}
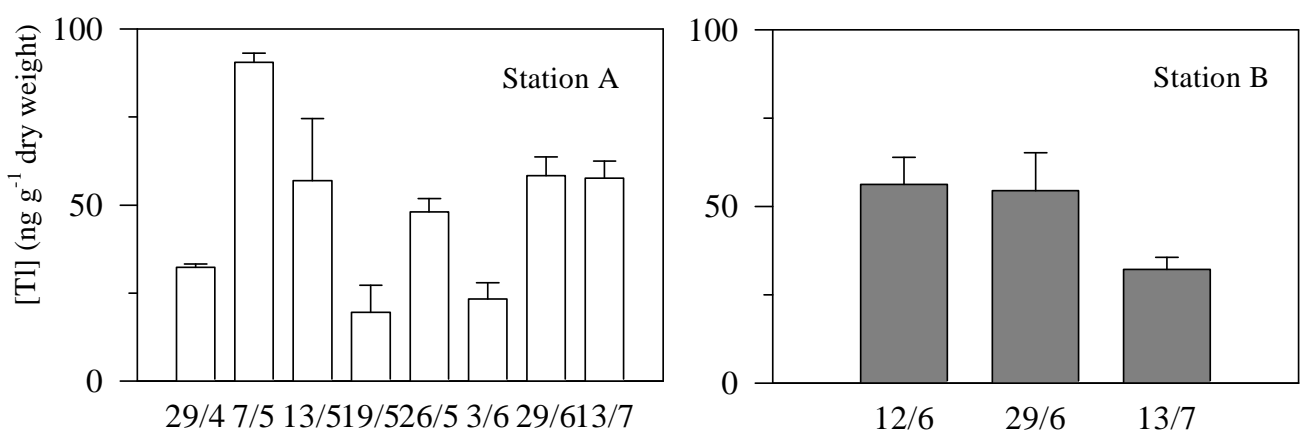

Sampling date

Figure 3. Histograms of dry-weight thallium concentrations measured in the oyster Crassostrea angulata at two different stations ( $\mathrm{A}$ and $\mathrm{B}$ ) in the Guadalquivir estuary.

Figura 3. Histogramas de las concentraciones de talio en peso seco medidas en la ostra Crassostrea angulata en dos estaciones diferentes (A y B) en el estuario del Guadalquivir.

be sure that the behavior of non-thallium bioaccumulation in field organisms shown in this study continues.

\section{Field sediment toxicity testing}

The results of the sediment field test using unpolluted oyster specimens are summarized in table 3 for thallium and for the other two heavy metals considered (cadmium and lead). From the table it is clear that cadmium and lead present an increase in their concentrations with time. In this sense, and for the concentrations expressed as $\mu \mathrm{g} \mathrm{g}^{-1}$ dry weight, the trend in the accumulation of metals for the first and second month compared to that of time equal to zero (the time at which the organisms were placed in cages in the sediments of the Guadalquivir estuary) was $\mathrm{Cd}>\mathrm{Pb}>\mathrm{Tl}$.

These results show that the accumulation in the other two metals considered was higher than that of thallium. Also, and compared to the results obtained for Lake Ontario (table 2), the thallium de acumulación, que debería confirmarse en análisis posteriores, debido a la baja frecuencia de las fechas de muestreo (únicamente dos fechas, una en junio y otra en julio). Los resultados estuvieron comprendidos entre 59 y $128 \mathrm{ng} \mathrm{g}^{-1}$ en peso seco.

Los resultados de la concentración de talio en la ostra $C$. angulata, procedente de dos estaciones diferentes del río Guadalquivir, se muestran en la figura 3. El intervalo de concentración obtenido fue de 20 a $90 \mathrm{ng} \mathrm{g}^{-1}$ en peso seco. Estos resultados presentan una variabilidad considerable; sin embargo, no se observa ningún proceso de bioacumulación para este organismo. Las diferencias entre estaciones no fueron significativas $(P<0.01)$.

Como no se dispone de datos de otros organismos marinos similares, no se han podido comparar estos resultados con los de especies procedentes de otros ecosistemas marinos o estuáricos. No obstante, se comparan con los datos obtenidos por Borgmann et al. (1998) para el anfípodo de agua dulce Hyalella azteca, que fue 
Ciencias Marinas, Vol. 25, No. 2, 1999

Table 1. Thallium concentrations $\left( \pm \sigma_{\mathrm{n}-1}\right)$, expressed as $\mu \mathrm{g} \mathrm{g}{ }^{-1}$ dry weight, in male and female specimens of the crab Uca tangeri at two different stations (D and $\mathrm{E}$ ) in the Guadalquivir estuary.

Tabla 1. Valores de concentración de talio $\left( \pm \sigma_{\mathrm{n}-1}\right)$, expresados en $\mu \mathrm{g} \mathrm{g}^{-1}$ peso seco, en ejemplares machos y hembras del cangrejo Uca tangeri procedentes de dos estaciones (D y E) del estuario del Guadalquivir.

\begin{tabular}{cccc}
\hline Station & Date & Male & Female \\
\hline D & June & & $58.72 \pm 6.38$ \\
& July & $128.30 \pm 20.17$ & $122.45 \pm 21.90$ \\
& & & $85.46 \pm 6.44$ \\
E & June & & $117.38 \pm 16.51$ \\
\hline
\end{tabular}

Table 2. Comparison of thallium concentration (ng g ${ }^{-1}$ dry weight) for the fresh-water amphipod exposed to sediment from Lake Ontario (Borgmann et al., 1998) and the organisms used in this study from the Guadalquivir estuary.

Tabla 2. Comparación de la concentración de talio (ng g-1 peso seco) del anfípodo de agua dulce expuesto al sedimento del Lago Ontario (Borgmann et al., 1998) con la de aquellos organismos del estuario del Guadalquivir utilizados en este trabajo.

\begin{tabular}{lccccc}
\hline & $\begin{array}{c}\text { Hyalella } \\
\text { azteca }\end{array}$ & $\begin{array}{c}\text { Scrobicularia } \\
\text { plana }\end{array}$ & $\begin{array}{c}\text { Liza } \\
\text { ramada }\end{array}$ & $\begin{array}{c}\text { Uca } \\
\text { tangeri }\end{array}$ & $\begin{array}{c}\text { Crassostrea } \\
\text { angulata }\end{array}$ \\
\hline Minimum & 155 & 42 & 70 & 50 & 20 \\
Maximum & 1001 & 100 & 200 & 125 & 90 \\
\hline
\end{tabular}

accumulation results obtained in the Guadalquivir estuary experiment for the oyster (C. angulata) specimens were lower than the thallium accumulation results for the amphipod (H. azteca) from the Lake Ontario experiment. Unfortunately, similar field sediment test data from estuarine or marine areas are not available and thus cannot be compared.

\section{CONCLUSIONS}

This study presents the results of a chemical analysis and biological assessment of several samples from different organisms collected in the Guadalquivir estuary after the mining spill that occurred in the Aznalcóllar pyrite mine, which expuesto a diferentes concentraciones de talio en sedimentos del Lago Ontario (tabla 2). De estos resultados se observa que sólo un máximo registrado en el río Guadalquivir fue superior al mínimo encontrado en los anfípodos del Lago Ontario. Es necesario tener en cuenta que dicho máximo corresponde a un pez adulto y que, además, fue hallado en el hígado. Se puede concluir a partir de esta comparación que los niveles de talio encontrados en los organismos marinos seleccionados para este trabajo fueron inferiores a los de los anfípodos del Lago Ontario. Éste es otro resultado que confirma nuestra idea de que no existe efecto debido al talio en el estuario del Guadalquivir. Sin embargo, este estudio de seguimiento en los organismos del estuario debería realizarse en 
DelValls et al.: Thallium in the marine environment

Table 3. Heavy metal concentrations for cadium, lead and thallium measured in the oyster (Crassostrea angulata); caged specimens transported from an uncontaminated site in the Bay of Cádiz and introduced into an area of the Guadalquivir River potentially affected by the Aznalcóllar mining spill. The results are expressed as dry weight.

Tabla 3. Valores de concentración de metales pesados para el cadmio, plomo y talio medidos en la ostra (Crassostrea angulata); ejemplares transportados desde una zona no contaminada de la Bahía de Cádiz a un área del río Guadalquivir potencialmente afectada por el vertido minero de Aznalcóllar e introducidos aquí en jaulas. Los resultados se expresan en peso seco.

\begin{tabular}{lccc}
\hline Date & {$[\mathrm{Cd}]\left(\mu \mathrm{g} \mathrm{g}^{-1}\right)$} & {$[\mathrm{Pb}]\left(\mu \mathrm{g} \mathrm{g}^{-1}\right)$} & {$[\mathrm{Tl}]\left(\mathrm{ng} \mathrm{g}^{-1}\right)$} \\
\hline $29 / 07(t=0)$ & $0.70 \pm 0.09$ & $0.94 \pm 0.07$ & $59.23 \pm 9.35$ \\
$24 / 08(t=1$ month $)$ & $2.69 \pm 0.20$ & $1.39 \pm 0.10$ & $80.12 \pm 5.56$ \\
$29 / 09(t=2$ months $)$ & $3.15 \pm 0.06$ & $1.80 \pm 0.14$ & $60.80 \pm 14.83$ \\
\hline Ratio $(t=1$ month $/ t=0)$ & 3.84 & 1.48 & 1.35 \\
Ratio $(t=2$ months $/ t=0)$ & 4.50 & 1.91 & 1.03 \\
Ratio $(t=2$ months $/ t=1$ month $)$ & 1.17 & 1.29 & \\
\hline
\end{tabular}

provide an image of the bioaccumulation and potential ecotoxicity due to highly toxic and unknown chemicals, such as thallium, in the marine environment. Within the context of this study, we have attempted to provide a snapshot of the behavior and toxicity of thallium in marine environments by reviewing its sources, occurrences, properties, biological functions, metabolisms and general toxicity. Also, we have provided the first field data of this metal in the marine environment by measuring the level of thallium in different important organisms of the food chain in the Guadalquivir estuary. Furthermore, we have attempted to describe the first ecotoxicological assessment of thallium in the oyster from the area studied by performing a field sediment toxicity test.

Although no bioaccumulation or ecotoxicity of thallium was measured, further similar studies should be conducted to evaluate the potentiality of this metal to accumulate and, more specifically, the environmental sediment quality in the Guadalquivir River and in the important area of the Doñana Natural Reserve. el futuro (actualmente, el programa de seguimiento continúa y va a permitir incrementar la base de datos de que se dispone) para tener seguridad de que se mantiene el comportamiento de no bioacumulación de talio en los organismos in situ observado en este trabajo.

\section{Test de toxicidad in situ}

En la tabla 3 se presentan los resultados del test de toxicidad in situ para el talio y para los otros dos metales pesados considerados (cadmio y plomo) obtenidos al utilizar ejemplares de la ostra $C$. angulata procedentes de una zona no contaminada de la Bahía de Cádiz. Se observa que el cadmio y el plomo muestran un incremento en su concentración con el tiempo. En este sentido, y para las concentraciones expresadas como $\mu \mathrm{g} \mathrm{g}^{-1}$ en peso seco, la tendencia en la acumulación de metales en el primer y segundo mes comparada con la del tiempo igual a cero (tiempo en el cual los organismos se colocaron en jaulas en los sedimentos del estuario del Guadalquivir) fue $\mathrm{Cd}>\mathrm{Pb}>\mathrm{Tl}$. 
Ciencias Marinas, Vol. 25, No. 2, 1999

\section{ACKNOWLEDGEMENTS}

This study was performed as part of the expert commission for the monitoring of the impact of the Aznalcóllar mining spill. The authors especially thank María Francisca Osta, Isabel Fernández, Pablo Vidal and Carmen Francoy for their assistance during the sampling and the treatment of the samples before analysis.

\section{REFERENCES}

ACGIH (1995). Threshold limit values and biological exposure indices for 1992-1993. American Conference of Governmental Industrial Hygienists, Cincinnati, Ohio.

Amiard, J.C., Pineau, A., Boiteau, H.L., Metayer, C. and Amiard-Triquet, C. (1987). Application of atomic absorption spectrophotometry using Zeeman effect to the determination of eight trace elements ( $\mathrm{Ag}, \mathrm{Cd}, \mathrm{Cr}, \mathrm{Cu}, \mathrm{Mn}, \mathrm{Ni}, \mathrm{Pb}$ and $\mathrm{Se}$ ) in biological materials. Wat. Res., 21(6): 693-697.

Beliles, R.P. (1994). The metals. 31. Thallium. In: J.D. Clayton and F.E. Clayton (eds.), Patty's Industrial Hygiene and Toxicology, 42nd ed., Vol. Iic. Wiley Interscience, New York, pp. 2235-2241.

Borgmann, U., Cheam, V., Norwood, W.P. and Lechner, J. (1998). Toxicity and bioaccumulation of thallium in Hyalella azteca, with comparison to other metals and prediction of environmental impact. Environ. Pollut., 99: 105-114.

Cheam, V., Lechner, J., Desrosiers, R. and Sekerka, I. (1996). Direct determination of dissolved and total thallium in lake waters by Laser-Excited Atomic Fluorescence Spectrometry. Inter. J. Environ. Anal. Chem., 63: 153-165.

Keith, L.H. and Telliard, W.A. (1979). Priority pollutants. I. A perspective view. Environ. Sci. Technol., 13: 416-423.

Korenman, M. (1963). Analytical Chemistry of Thallium. S. Monson, Jerusalem, 138 pp.

Manzo, L., Minoia, C. and Sabbioni, E. (1995). Toxicity of detrimental metal ions: Thallium. In: G. Berthon (ed.), Handbook of Metal-ligand Interactions in Biological Fluids. Marcel Dekker, New York, pp. 766-771.

Munch, J.C. (1934). Human thallotoxicosis. J. Am. Med. Assoc., 102: 1929-1934.
Se observa que la acumulación de los otros dos metales considerados en el análisis fue superior a la del talio. También, y comparando con los datos del Lago Ontario (tabla 2), los resultados de la acumulación de talio obtenidos en el experimento del estuario del Guadalquivir para los ejemplares de la ostra ( $C$. angulata) fueron más bajos que los resultados de la acumulación de talio para el anfípodo (H. azteca) del experimento del Lago Ontario. Desafortunadamente, no se dispone para zonas estuáricas o marinas de más datos de otros tests de toxicidad in situ similares y, por tanto, estos datos no pueden compararse de una forma más efectiva.

\section{CONCLUSIONES}

Este trabajo presenta los resultados del análisis químico y la evaluación biológica de muestras de diferentes organismos recogidos en el estuario del Guadalquivir después del vertido minero ocurrido en la mina de pirita de Aznalcóllar, que proporcionan una imagen de la bioacumulación y ecotoxicidad potencial debidas a contaminantes altamente tóxicos y desconocidos, como el talio en el medio marino. Dentro del contexto de este trabajo, se ha intentado proporcionar una instantánea del comportamiento y toxicidad del talio en el medio marino mediante la revisión de sus fuentes, presencia, propiedades, funciones biológicas, metabolismo y toxicidad general. También se han presentado los primeros datos de campo de este metal en el medio marino a través de la determinación de los niveles de talio en diferentes organismos de gran importancia en la cadena trófica del estuario del Guadalquivir. Además, se ha descrito la primera valoración ecotoxicológica del talio en la ostra $C$. angulata por medio de tests de toxicidad in situ.

Aunque no se detectó ni bioacumulación ni ecotoxicidad de talio se deberían seguir realizando futuros estudios de este tipo y utilizando un punto de vista integral para evaluar la potencialidad de este metal para acumularse, y también estudios más específicos de la calidad ambiental 
DelValls et al.: Thallium in the marine environment

Oheme, F.W. (1978). Toxicity of Heavy Metals in the Environment. Vol. 2. Marcel Dekker, New York.

Spencer, E.R., Peterson, R., Madrid, R. and Raine, C.S. (1976). Effects of thallium salts on neuronal mitochondria in organotype cord-ganglia-muscle combination cultures. J. Cell Biol., 58: 79-85.

Wedepohl, K.H. (1991). The composition of the upper earth's crust and the natural cycles of selected metals. Metals in natural raw materials. Natural resource. In: E. Merian (ed.), Metals and their Compounds in the Environment, Occurrence, Analysis and Biological Relevance. $\mathrm{VCH}$, Weinheim, pp. 1-17. de los sistemas del río Guadalquivir y de la Reserva Natural Doñana.

\section{AGRADECIMIENTOS}

Este trabajo forma parte del seguimiento llevado a cabo por la comisión de expertos para la evaluación del impacto del vertido minero de Aznalcóllar. Los autores agradecen especialmente a María Francisca Osta, a Isabel Fernández, a Pablo Vidal y a Carmen Francoy su asistencia durante el muestreo y tratamiento de las muestras previos al análisis.

Traducido al español por los autores. 